\title{
Regulation of an anthranilate synthase gene in Streptomyces venezuelae by a trp attenuator
}

\author{
Cong Lin, † Ashish S. Paradkarł and Leo C. Vining \\ Author for correspondence: Leo C. Vining. Tel: +1902 494 2040. Fax: +1 9024943736. \\ e-mail: Leo.Vining@Dal.Ca
}

Biology Department, Dalhousie University, Halifax, NS, Canada B3H 4J1

\begin{abstract}
The nucleotide sequence of a $2 \cdot 4 \mathrm{~kb}$ BamHl-Sall fragment of Streptomyces venezuelae ISP5230 DNA that complements trpE and trpG mutations in Escherichia colf contains two ORFs. The larger of these (ORF2) encodes a 624 amino acid sequence similar to the overall sequence of the two subunits of anthranilate synthase. The two-thirds nearest the amino terminus resembles the aminase subunit; the remaining one-third resembles the glutamine amidotransferase subunit. Upstream of ORF2 is a small ORF encoding 18 amino acids that include three adjacent Trp residues; in addition the ORF contains inverted repeats with sequence and positional similarity to the products of attenuator (trpL) regions that regulate tryptophan biosynthesis in other bacteria. In cultures of a trpC mutant of $S$. venezuelae, increasing the concentration of exogenous tryptophan decreased the formation of anthranilate synthase; similar evidence of endproduct repression was obtained in a trpCER mutant of $E$. coli transformed with a vector containing the cloned DNA fragment from $S$. venezuelae. The anthranilate synthase activity in S. venezuelae cell extracts was inhibited by tryptophan, although only at high concentrations of the amino acid. A two-base deletion introduced into the cloned $S$. venezuelae DNA fragment prevented complementation of a trpE mutation in E. colf. However, S. venezuelae transformants in which the two-base deletion had been introduced by replacement of homologous chromosomal DNA did not exhibit a Trp- phenotype. The result implies that 5 . venezuelae has one or more additional genes for anthranilate synthase. In alignments with anthranilate synthase genes from other organisms, ORF2 from S. venezuelae most closely resembled genes for phenazine biosynthesis in Pseudomonas. The results bear on the function of the gene in S. venezuelae.
\end{abstract}

Keywords: anthranilate synthase genes, attenuator, gene disruption, nucleotide sequence

\section{INTRODUCTION}

Anthranilate synthase (AS) is the first enzyme in the branch of the aromatic biosynthesis pathway leading specifically to tryptophan. In most organisms, the

\footnotetext{
†Present address: DataMirror, 3100 Steeles Ave E, Suite 700, Markham, Ontario, Canada L3R 8T3.

‡Present address: M330 Biological Sciences Building, University of Alberta, Edmonton, Alberta, Canada T6G 2E9.

Abbreviation: AS, anthranilate synthase.

The GenBank accession number for the nucleotide sequence reported in this paper is AF012627.
}

enzyme has two non-identical subunits; the larger one (ASI), encoded by $\operatorname{trpE}$, can by itself synthesize anthranilate from chorismate in the presence of a relatively large concentration of ammonia. The smaller subunit (ASII), encoded by $\operatorname{trpG}$, is a glutamine amidotransferase, and can generate the amino group of anthranilate from moderate concentrations of glutamine, thereby avoiding $\mathrm{pH}$ effects due to high cellular levels of ammonia (Crawford, 1989). The subunits of AS are most commonly monofunctional proteins, although in some organisms a subunit protein catalyses more than one of the activities required for tryptophan synthesis [e.g. $\operatorname{Trp}(G) D$ in Escherichia coli and Salmonella typhimurium; Huang \& Zalkin, 1971]. 
The flow of metabolic intermediates to tryptophan is regulated by controlling transcription, as well as by feedback inhibition of AS activity. The latter is a highly conserved feature in all micro-organisms (Bae \& Crawford, 1990), but transcriptional controls are more diverse. In E. coli and some other bacteria, trp genes constitute a single operon regulated by both repression and attenuation, with the region responsible for attenuation located immediately upstream of $\operatorname{tr} p E$. Although the regulation of bacterial tryptophan biosynthesis has received a lot of attention, it has not been investigated in streptomycetes. Streptomyces venezuelae, in which the chromosomal organization of $t r p$ genes is known to differ from that in other bacteria, contains AS genes separated from a $\operatorname{trp} C B A$ cluster, while $\operatorname{trpD}$ and $\operatorname{trpF}$ are at a third locus (Paradkar et al., 1993). Whether genes at the three loci are coordinately regulated has not been investigated. There is some evidence for attenuation as a mechanism controlling gene expression in streptomycetes (cited in Potter \& Baumberg, 1996) but as yet there is no fully documented example of an attenuator with a role in regulating a primary biosynthetic pathway. The cloning from $S$. venezuelae of a DNA fragment encoding AS activity (Paradkar et al., 1991a) provided us with an opportunity to examine the organization, regulation and evolutionary relationships of AS genes in this species. The biosynthesis of chorismate-derived metabolites is of particular interest in S. venezuelae since the antibiotic chloramphenicol is one of the endproducts of the aromatic pathway (Vining \& Stuttard, 1994).

\section{METHODS}

Bacteria, plasmids and culture media. The micro-organisms and plasmids used are described in Table 1 . Strains of $S$. venezuelae were maintained on MYM agar (Stuttard, 1982). The minimal medium (MM) used for S. venezuelae cultures grown on agar was the maltose/asparagine/salts medium of Hopwood et al. (1985). The tryptophan-free medium used for liquid cultures of $S$. venezuelae was prepared as described by Hopwood et al. (1985) but contained (per litre): glucose $(10 \mathrm{~g})$, maltose $(5 \mathrm{~g})$, asparagine $(0.5 \mathrm{~g})$, vitamin-free Casamino acids (5.0 g; Difco), $\mathrm{MgSO}_{4} .7 \mathrm{H}_{2} \mathrm{O}(0.6 \mathrm{~g}), 0.1 \mathrm{M}$ $\mathrm{NaH}_{2} \mathrm{PO}_{4} / \mathrm{K}_{2} \mathrm{HPO}_{4}$ buffer, $\mathrm{pH} 6.8$ (150 ml), and the minor elements solution (1 ml) of Hopwood et al. (1985). For E. coli, LB medium or M9 (glucose/ammonium chloride/salts) minimal medium was used (Sambrook et al., 1989). For strains derived from $E$. coli JA221 and JA200, M9 medium was supplemented as needed with amino acids at $10 \mathrm{mg} \mathrm{ml}^{-1}$, and thiamin at $1 \mathrm{mg} \mathrm{m}^{-1}$. Cultures of $E$. coli W3110 trpCER (pDQ187) used to determine the effect of tryptophan on expression of $\operatorname{trp} E(G)$ were grown in M9 medium supplemented with vitamin-free Casamino acids at $0.5 \mathrm{mg} \mathrm{ml}^{-1}$ and ampicillin at $0 \cdot 1 \mathrm{mg} \mathrm{ml}^{-1}$.

DNA manipulations. The general procedures described by Sambrook et al. (1989) were followed. Plasmid DNA was isolated from $E$. coli by the alkaline lysis method (Kieser, 1984), except during the screening of colonies, when the boiling method of Holmes \& Quigley (1981) was adopted. Genomic DNA was obtained as described by Hopwood et al. (1985).

Transformation procedures. Competent cells of $E$. coli trp auxotrophs were prepared and transformed as described by

Table 1. Bacterial strains and plasmids used

\begin{tabular}{|c|c|c|}
\hline Strain or plasmid & Genotype/phenotype & Source/reference \\
\hline \multicolumn{3}{|l|}{$\begin{array}{c}\text { Streptomyces } \\
\text { venezuelae }\end{array}$} \\
\hline ISP5230 & Wild-type & Doull et al. (1985) \\
\hline VS153 & $\operatorname{trpC} \mathrm{cml}-5$ & Stuttard (1983) \\
\hline VS194 & bis $A 6$ adeA10 SVP1- SVP2- & Doull et al. (1986) \\
\hline AP55 & VS194 with a mutation in $\operatorname{trp} E(G)$ & This work \\
\hline \multicolumn{3}{|l|}{ Escherichia coli } \\
\hline TG1 & 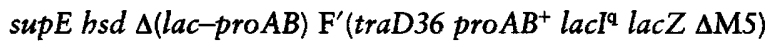 & Carter et al. (1985) \\
\hline JA221 & $r^{-} m^{+}$leu thi $\Delta t r p E 5$ & C. Yanofsky, Stanford University \\
\hline JA200 & $\begin{array}{l}\text { thr-1 leuB6 } \Delta \text { trpE63 recA56 thi-1 ara-14 lacY1 galK2 xyl-5 } \\
\text { mtl-1 } \lambda^{-} \text {supE44 }\end{array}$ & CGSC 6059/Clarke \& Carbon (1976) \\
\hline W3110 $\operatorname{trpC}$ & $\operatorname{trp} C$ & C. Yanofsky, Stanford University \\
\hline W3110 trpCER & $\operatorname{trpC} 10243 \operatorname{trpE9829} \operatorname{trpR}$ & C. Yanofsky, Stanford University \\
\hline \multicolumn{3}{|l|}{ Plasmids } \\
\hline pHJL400 & Bifunctional $\operatorname{Par}^{-} \mathrm{Ap}^{\mathrm{R}} \mathrm{Ts}^{\mathrm{R}}$ & Larson \& Hershberger (1986) \\
\hline pDQ187 & pTZ18R with a $2.4 \mathrm{~kb} \operatorname{trp} E(G)$ insert & Paradkar et al. (1991a) \\
\hline pDQ189 & pHJL400 with a $2.4 \mathrm{~kb} \operatorname{trp} E(G)$ insert & Paradkar et al. (1993) \\
\hline pDQ190 & pTZ18R with a modified $\operatorname{trpE}(G)$ insert & This work \\
\hline pDQ191 & pHJL400 with a modified $\operatorname{trp} E(G)$ insert & This work \\
\hline pDQ192-193 & pBluescriptII $S K(+)$ with $\operatorname{trpE}(G)$ insert & This work \\
\hline pDQ290 & pBR322 with a $2.7 \mathrm{~kb}$ pabB pabA insert & Arhin \& Vining (1993) \\
\hline
\end{tabular}


Kushner (1978). For other E. coli strains the procedure of Hopwood et al. (1985) was used. Transformants were plated on LB agar (Sambrook et al., 1989) containing ampicillin $\left(0.1 \mathrm{mg} \mathrm{m}^{-1}\right)$. A genomic library was prepared by partially digesting DNA from $S$, venezuelae ISP5230 with MboI and size-fractionating it in a sucrose gradient to give $6-12 \mathrm{~kb}$ fragments. The fragments were ligated to $\mathrm{pTZ18R}$ that had been linearized with BamHI and dephosphorylated (Sambrook et al.,1989). The ligation mixture was used to transform E. coli JA221 ( $\Delta t r p E)$ to protototrophy. For introducing plasmid DNA into S. venezuelae we used strain VS194, which is transformed more efficiently than the wild-type strain ISP5230.

Gene disruption. pDQ187 was linearized by digestion with $M l u I$, incubated with mung bean nuclease and treated with the Klenow fragment of DNA polymerase I. The blunt ends were ligated and the recircularized plasmid was used to transform E. coli JA200. Plasmid DNA isolated from Trp ${ }^{-}$transformants was screened for loss of the MluI site by gel electrophoresis of $E c o R I$ and $M l u I$ digests.

DNA sequencing and sequence analysis. Both orientations of the DNA fragment cloned in $\mathrm{pDQ} 187$ were subcloned in the phagemid vector pBluescriptII $S K(+)$, and overlapping deletion clones were generated. Single-stranded DNA templates were isolated as described by Karger \& Jessee (1990) from cultures of $E$. coli TG1 transformed with the phagemid and infected with helper phage VCSM13 (Stratagene). The DNA strands were sequenced by the dideoxy chain-termination procedure (Sanger et al., 1977) using Sequenase version 2.0 (Amersham) and $\left.{ }^{35} \mathrm{~S}\right] \mathrm{dATP} \alpha-\mathrm{S}$. The sequence was analysed with GCG software (Genetics Computer Group). The region containing the MluI site in pDQ191 was sequenced using the double-stranded cloned DNA insert as the template and a synthetic oligonucleotide primer.

Hybridization. Plasmids and genomic DNA digested with restriction enzymes were fractionated by electrophoresis and the DNA was transferred to Hybond-N nylon membranes (Amersham) as described by Southern (1975). DNA probes were labelled with $\left[\alpha_{-}{ }^{32} \mathrm{P}\right] \mathrm{dCTP}$ by the random priming procedure. Hybridization was carried out at $65^{\circ} \mathrm{C}$ in a solution containing $5 \times$ SSPE (SSPE is $0.18 \mathrm{M} \mathrm{NaCl}, 10 \mathrm{mM}$ $\mathrm{Na}_{2} \mathrm{HPO}_{4}$ and $1 \mathrm{mM}$ EDTA, $\mathrm{pH} 7 \cdot 7$ ), $5 \times$ Denhardt's solution (Denhardt, 1966), 0.5\% SDS and denatured salmon sperm DNA $\left(200 \mu \mathrm{g} \mathrm{ml}^{-1}\right)$. Membranes were routinely washed at $65^{\circ} \mathrm{C}$ with SSPE solutions (twice with $2 \times$, then with $1 \times$ and $0.1 \times$ ), all containing $0.1 \%$ SDS. The stringency of the wash should have removed DNA of lower than $70 \%$ sequence identity with the probe. [ ${ }^{32}$ P]DNA was detected by autoradiography.

Enzyme assays. Cells from cultures of $E$. coli or $S$. venezuelae were harvested by centrifugation and washed with extraction buffer. Extraction buffer for $E$. coli contained $0 \cdot 1 \mathrm{M}$ potassium phosphate, pH 7.8, $1 \mathrm{mM}$ EDTA and $1 \mathrm{mM}$ DTT (Smith \& Yanofsky, 1963); for S. venezuelae it contained $0.1 \mathrm{M}$ potassium phosphate, $\mathrm{pH} 7.8,0.5 \mathrm{M}$ potassium chloride, $0.1 \mathrm{mM}$ EDTA, 0.8 M sucrose and $6 \mathrm{mM} 2$-mercaptoethanol (Smithers \& Engel, 1974). Washed cells were resuspended in the buffer, disrupted by sonication and centrifuged. The supernatant solution was used as the cell extract. All procedures during and after harvest were at $4{ }^{\circ} \mathrm{C}$. AS was assayed by incubating cell extracts at $37^{\circ} \mathrm{C}$ for $30 \mathrm{~min}$ with chorismic acid $(1 \mu \mathrm{mol})$, glutamine $(20 \mu \mathrm{mol})$, magnesium chloride $(10 \mu \mathrm{mol})$ and Tris $/ \mathrm{HCl}(50 \mu \mathrm{mol}), \mathrm{pH} 7.5$ (final volume $1 \mathrm{ml})$. Anthranilic acid was measured in the deproteinized solution by diazotization and coupling with $N$-naphthylethylenediamine (Jones
\& Westlake, 1974). A unit of AS is defined as the amount of enzyme catalysing the formation of $1 \mathrm{nmol}$ anthranilic acid $\mathrm{min}^{-1}$. Protein was assayed with bicinchoninic acid (BCA protein assay reagent, Pierce; Smith, 1985) using bovine serum albumin as the standard. To avoid interference from tryptophan in assays for feedback effects on enzyme activity, anthranilic acid was extracted from acidified reaction mixtures with ethyl acetate. After back-extraction with aqueous buffer at $\mathrm{pH} 4.5$, the solvent was evaporated and the residue, redissolved in water, was assayed colorimetrically as above. To confirm the identity of the enzyme reaction product, the residue from representative assays was examined by TLC on silica gel plates using toluene/acetic acid $(19: 1, \mathrm{v} / \mathrm{v})$ as the mobile phase. Anthranilic acid was distinguished as a bluefluorescent zone at $R_{F} \mathbf{0 . 2 8}$, giving a purple colour after spraying with $5 \%$ sodium nitrite in $0 \cdot 1 \mathrm{M}$ hydrochloric acid and overspraying with $0.2 \% \mathrm{~N}$-naphthylethylenediamine in $2 \mathrm{M}$ hydrochloric acid. Neither $p$-aminobenzoic acid (purple zone at $\left.R_{F} 0.18\right)$ nor indole $\left(R_{F} 0.58\right)$ was formed in the enzyme reaction mixtures.

\section{RESULTS}

\section{Nucleotide sequence of the DNA fragment encoding anthranilate synthase}

The $2.4 \mathrm{~kb}$ fragment of $S$. venezuelae DNA cloned in the recombinant E. coli plasmid pDQ187 (Paradkar et al., 1991a) was excised as a BamHI-Sall fragment. It was blunt-ended by treatment with the Klenow fragment of DNA polymerase I, and subcloned (both orientations) in the EcoRV site of pBluescriptII SK $(+)$. Single-stranded DNA from each of the phagemids (Vieira \& Messing, 1987) was sequenced. Analysis of the nucleotide sequence using the CODONPREFERENCE program (Devereux et al., 1984) with the codon usage table for streptomycetes compiled by Wright \& Bibb (1992) indicated that the $2.4 \mathrm{~kb}$ fragment contains a small ORF (ORF1) followed by a much larger one (ORF2; see Fig. 1). ORF1 begins with an ATG codon at nt 93-95 and ends with the TGA codon at nt 147-149. The region upstream of the translational start codon does not show an obvious RBS, but at nt 81-86 the sequence TACAGT fits the consensus (TAgPuPuT) for the -10 hexamer of

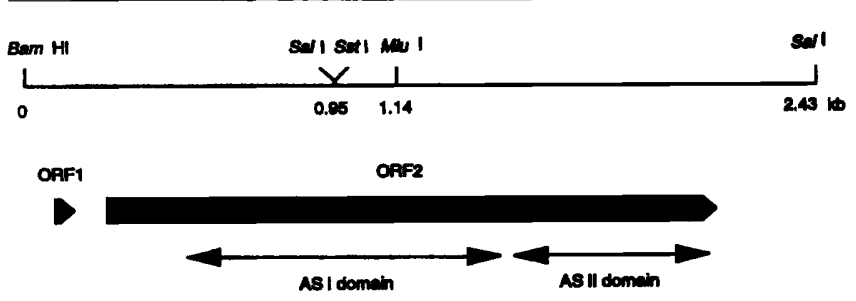

Fig. 1. The $2.43 \mathrm{~kb}$ BamHI-Sall fragment of $S$. venezuelae DNA cloned in PDQ187 (Paradkar et al., 1991a). The nucleotide sequence was determined after recloning the DNA insert in pBluescriptll SK( + ), and ORFs were detected in the nucleotide sequence by codon usage analysis with the CODONPREFERENCE program of the GSG software package (Devereux et al., 1984). Regions in the deduced amino acid sequence showing similarity to ASI and ASII were identified by comparison with protein databases using BLASTP (Altschul et al., 1990). 
(a)

S. venezuelae

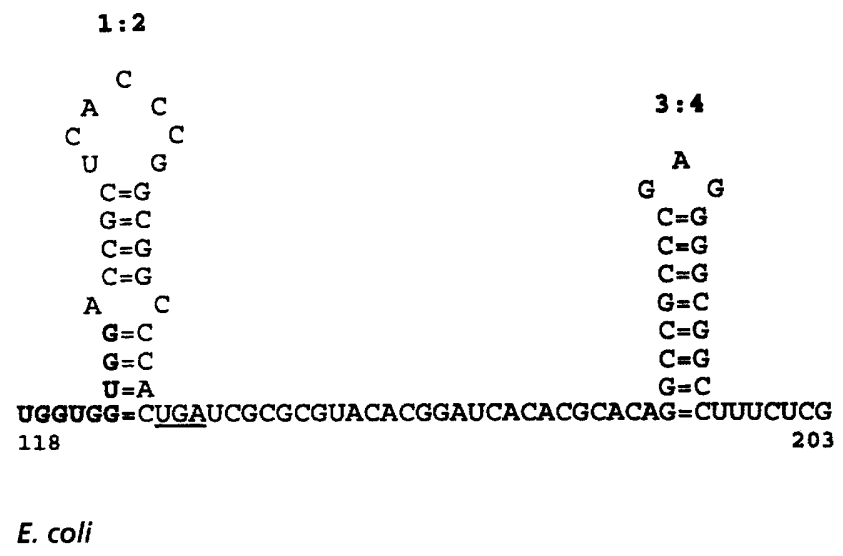

(b)

S. venezuelae

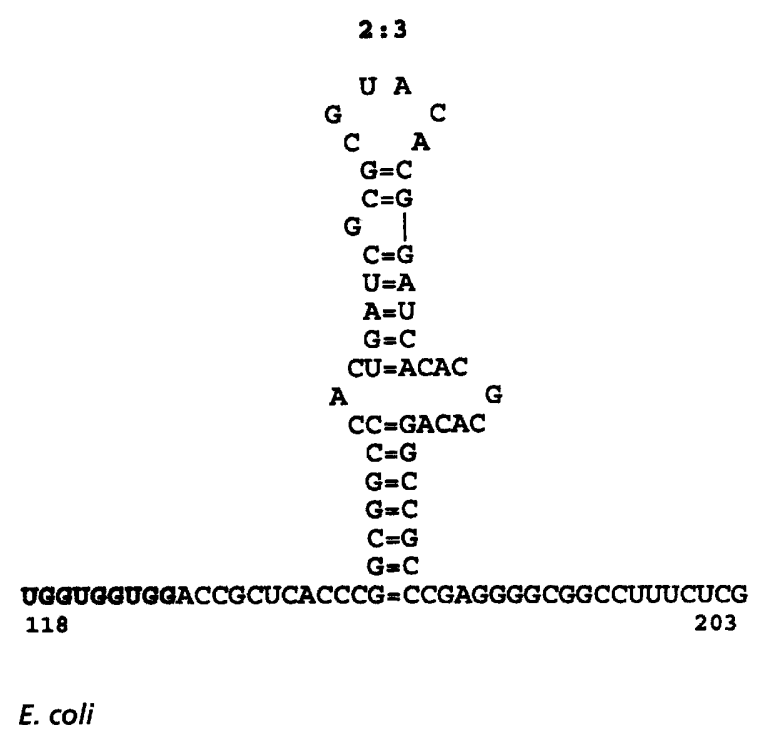

Fig. 2. Comparison of secondary structures postulated for trpL mRNA in $S$. venezuelae with those described for $E$. coli (Landick et al., 1996). (a) The 1:2 (pause) and 3:4 (terminator) stem-loop structures that result in transcription terminating when tryptophan is adequate. (b) The 2:3 (antiterminator) structures that allow tryptophan synthesis when the amino acid is depleted. Codons for tryptophan are in bold face; the translational stop codon is underlined. In the $E$. coli gene, nucleotides are numbered relative to the $5^{\prime}$ end of the transcript; in the $S$. venezuelae gene, numbering is from the 5 ' end of ORF2.

streptomycete promoter sequences recognized by $\sigma^{70}$ of E. coli RNA polymerase (Strohl, 1992); the corresponding -35 hexamer is not apparent, but a tandem six-base (GTTCCC) direct repeat is present at nt $61-66$ and 67-72. No indication of a palindromic operator sequence was found. ORF2 begins with ATG at nt 251-253 and terminates with TGA at nt 2120-2122. A putative RBS (GGA; $\Delta G-9.2 \mathrm{kcal} \mathrm{mol}^{-1} ;-38.5 \mathrm{~kJ} \mathrm{~mol}^{-1}$ ) at nt 244-246 is present five to seven bases upstream of the translational start codon; the upstream region lacks recognizable promoter sequences.

\section{Identity of ORF2}

The polypeptide encoded by ORF2 contains 624 aa. Comparison of the amino acid sequence in the $\mathrm{N}$ terminal region of the deduced ORF2 product with protein databases using BLASTP (Altschul et al., 1990) showed $29-34 \%$ identity to ASI of enteric bacteria in the overlap regions; the sequence of the $\mathrm{C}$-terminal region showed $30-33 \%$ identity to ASII. Alignment of the ASIlike domain in the ORF2 product with the deduced aminase products of $\operatorname{trp} E$ and $p a b B$, which have 

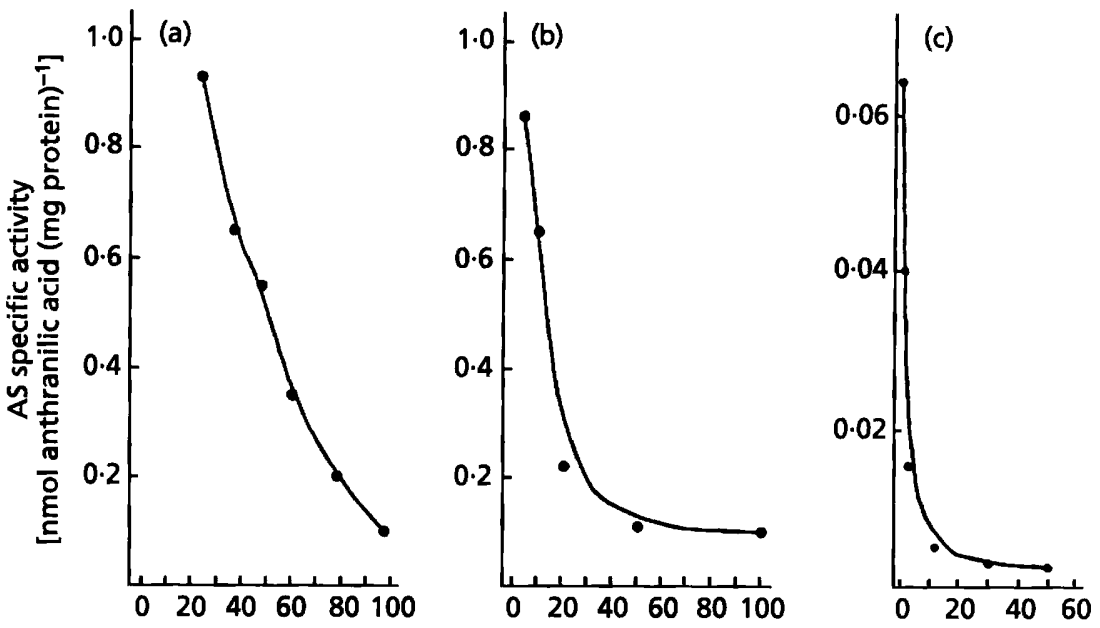

Tryptophan supplement in culture $(\mu \mathrm{M})$
Fig. 3. Specific activity of AS in cell extracts from cultures supplemented with increasing concentrations of tryptophan: (a) S. venezuelae VS153, (b) E. coli W3110 trpC and (c) E. coli W3110 trpCER(pDQ187). common ancestry (Goncharoff \& Nichols, 1984), and also with aminase products of related secondary metabolic pathway genes (see below) from a variety of bacteria, showed well-conserved sequence in this region. A similar alignment of the ASII-like domain with products from $\operatorname{trp} G, p a b A$ and related secondary metabolic pathway genes showed comparable sequence conservation in the C-terminal region of the ORF2 polypeptide. Relationships between the deduced protein sequences determined in alignments by the PILEUP program (Higgins \& Sharp, 1989) showed clustering of the products from both domains of $S$. venezuelae ORF2 with the corresponding products of $p h z B$ from Pseudomonas aureofaciens (Pierson et al., 1995), and of phzE from Pseudomonas fluorescens (Mavrodi et al., 1995). In a BLASTP search of the GenBank database the $p h z B$ and $p h z E$ gene products ranked highest in sequence similarity (56\% identical and $71 \%$ similar amino acids) to the product of ORF2 from $S$. venezuelae. As noted above, the percentage of identical amino acids in sequence comparisons between products from the ORF2 domains and those from $t r p$ and $p a b$ genes were much lower, ranging from 29 to $34 \%$. The $p h z$ gene products exhibit AS activity, and participate in the biosynthesis of phenazine metabolites (Pierson et al., 1995). In the two Pseudomonas species, as in S. venezuelae, both ASI and ASII are encoded by domains within a single ORF.

\section{Identity of ORF1}

The small ORF at nt 93-149, upstream of ORF2, contains codons for 18 amino acids. The size of the translated product is similar to that of leader peptides functioning as attenuators to regulate gene expression (Yanofsky, 1981; Crawford, 1989). A role in attenuation of a $t r p$ gene is supported by the presence in ORF1 of three Trp codons in tandem at nt 117-125. The location of the tandem codons matches that in the trpL genes of other bacteria; in other respects the deduced peptide sequences of these genes are not strongly conserved. Like known trp attenuators, the $S$. venezuelae sequence contains inverted repeats capable of forming alternative stem-loop mRNA structures (Yanofsky, 1984). In the region beginning within the tandem Trp codons, the pairing sequences would allow an initial 1:2 stem-loop ending with a translational stop codon (Fig. 2a). Formation of this stem-loop would allow folding of the subsequent RNA sequence to give the $G+C$-rich 3:4 stem-loop, which is followed by a U-rich sequence typical of rho-independent transcriptional terminators (Chater \& Hopwood, 1989). The 3:4 stem contains well-conserved nucleotide sequences matching those in the trp attenuators of E. coli and Rhizobium (Sinorbizobium) meliloti aligned by Bae et al. (1989). Recognizable also in the ORF1 sequence is an alternative $2: 3$ pattern (Fig. 2b) that could form a stem-loop if translation of the tandem Trp codons is prevented by tryptophan deficiency; in preempting the sequence giving the $1: 2$ and $3: 4$ structures this alternative stem-loop would act as an antiterminator.

\section{Regulation of anthranilate synthase}

When grown in minimal medium, S. venezuelae ISP 5230 mutants blocked at various steps in tryptophan biosynthesis contained cellular AS activity two orders of magnitude above the wild-type (Paradkar et al., 1991b). On the assumption that the difference in AS activity was due to differences in size of the cytoplasmic tryptophan/ tryptophanyl-tRNA ${ }^{\operatorname{Trp}}$ pools that regulate AS synthesis by feedback effects, we examined the response to tryptophan supplements of an $S$. venezuelae trpC mutant, where such pools should be depleted (Fig. 3a). As the exogenous tryptophan concentration was increased stepwise from 25 to $100 \mu \mathrm{M}$, the AS activity in rapidly growing mycelium was reduced $9 \cdot 5$-fold. For comparison, adding tryptophan to a $\operatorname{trp} C$ mutant of $E$. coli W 3110 caused a similar decrease in AS activity, but in a lower response range $(4-25 \mu \mathrm{M}$; Fig. $3 \mathrm{~b})$. The results were consistent with the presence of feedback repression in both organisms. The specific activity of AS extracted from the mycelium of VS153 and assayed in vitro with $0,0.06,0.25$ and $2 \mathrm{mM}$ tryptophan in the reaction mixture showed 6,28 and $44 \%$ inhibition, 
respectively, by the supplement. The results indicated that, although a relatively high concentration of tryptophan is required, feedback inhibition of enzyme activity could also be a factor in regulating tryptophan biosynthesis in S. venezuelae.

When the E. coli $\operatorname{trp} E$ mutant JA200 was transformed to prototrophy by introducing the cloned AS gene of $S$. venezuelae in $\mathrm{pDQ} 187$, the specific activity of AS from the mycelium of transformants grown in $\mathrm{M} 9$ minimal medium was below that in wild-type $S$. venezuelae $[0 \cdot 01$ versus $0.06 \mathrm{nmol}$ anthranilic acid $\mathrm{min}^{-1}$ (mg protein $)^{-1}$ ]; moreover, the AS specific activity was not reduced further by supplementing cultures with tryptophan. To avoid the presumed feedback effect of endogenous tryptophan synthesis, we used an E. coli W3110 $\operatorname{trpE}$ strain with additional mutations $(\operatorname{trp} C \operatorname{trpR})$ that maintained tryptophan auxotrophy in cultures transformed with $\mathrm{pDQ} 187$. As anticipated, transformants in minimal medium responded to tryptophan, but grew more slowly than the wild-type. The highest specific activity of AS in the E. coli trpCER mutant carrying pDQ187 was $0.063 \mathrm{nmol}$ anthranilic acid $\mathrm{min}^{-1}$ (mg protein $)^{-1}$ (Fig. 3c); this was much lower than that in $E$. coli W3110 trpC $\left[0.85 \mathrm{nmol}\right.$ anthranilic acid $\mathrm{min}^{-1}(\mathrm{mg}$ protein $)^{-1}$, where AS activity was expressed from the native E. coli $\operatorname{trp} E$ and $\operatorname{trp} G$ genes (Fig. 3b). The differences were reflected in the sensitivity of the two strains to exogenous tryptophan; in E. coli trpCER(pDQ187), repression of AS activity was virtually complete at $10 \mu \mathrm{M}$ tryptophan, whereas $E$. coli W3110 $\operatorname{trp} C$ required $50 \mu \mathrm{M}$ for a similar response. The results indicated that the cloned S. venezuelae DNA fragment mediated a weak feedback response to tryptophan when transferred to an E. coli host. The low level of enzyme activity and interference from tryptophan in the assay prevented accurate measurement of feedback inhibition in extracts of E. coli trpCER transformed with pDQ187.

\section{Gene disruption and replacement}

The ORF2 sequence in pDQ187 was disrupted by digesting the plasmid at its unique MluI site (see Fig. 1), and recircularizing the linear DNA after blunt-ending by the procedure of Anzai et al. (1988). Transformation of E. coli JA200 $(\operatorname{trpE})$ with the ligation mixture gave prototrophic and tryptophan-requiring colonies in about equal proportions. Plasmid pDQ190 isolated from one of the $\mathrm{Trp}^{-}$auxotrophs resembled pDQ187 in giving a single fragment of $5.3 \mathrm{~kb}$ by digestion with EcoRI, but was not digested by $M l u \mathrm{I}$. The insert was excised from pDQ190 as a $2.4 \mathrm{~kb}$ EcoRI-HindIII fragment, and ligated to the EcoRI and HindIII sites in pHJL400. Transformation of E. coli TG1 with the ligation mixture yielded $\mathrm{pDQ} 191$, which was then introduced into $S$. venezuelae VS194. Transformants selected for thiostrepton resistance were maintained without selection through three rounds of sporulation to allow loss of free plasmids. Reimposing selection for the antibiotic yielded resistant strains in which pDQ191 had integrated into the chromosome by a single crossover. (a)

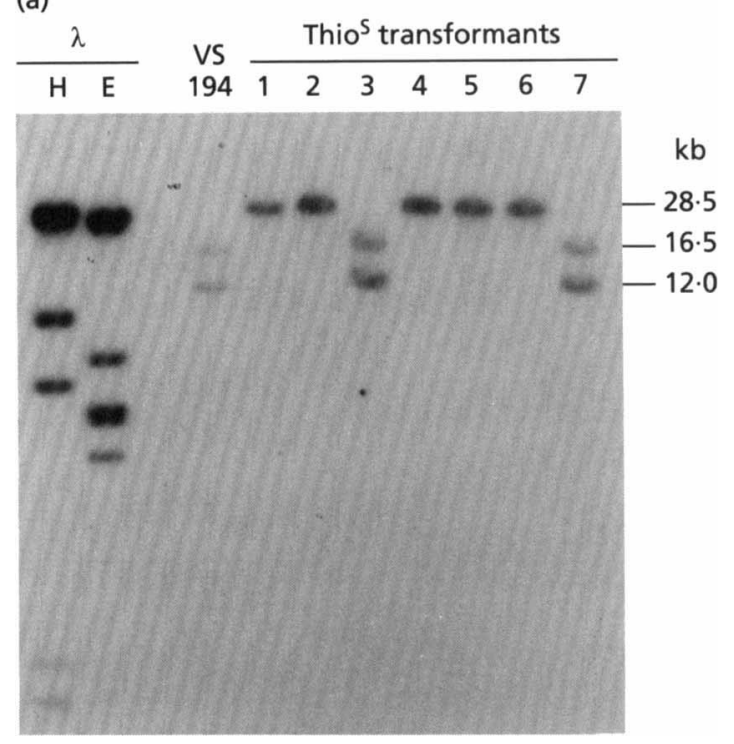

(b)

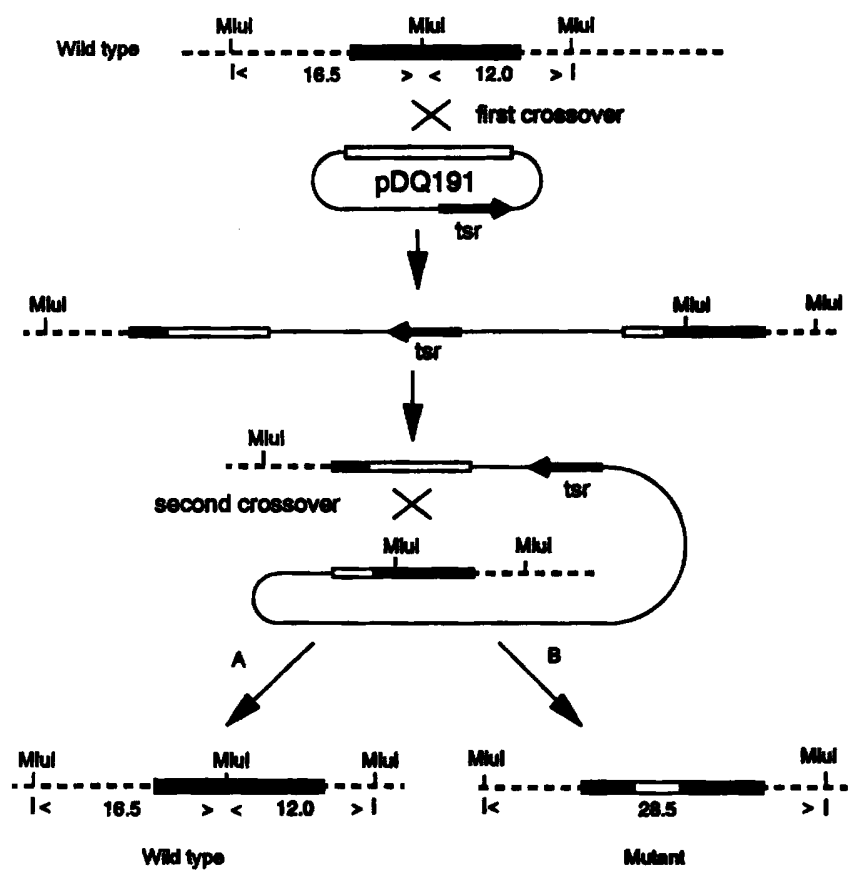

Fig. 4. (a) Southern hybridization of DNA digests probed with pDQ189. Lanes: $H$ and $E$, HindIII and EcoRI digests, respectively, of $\lambda$ DNA; VS194, Mlul digest of S. venezuelae VS194 genomic DNA; Thio ${ }^{5}$ transformants 1-7, Mlul digests of genomic DNA from $S$. venezuelae VS194(pDQ191) transformants that were Thio ${ }^{5}$ and failed to hybridize with pHJL400. (b) Model accounting for integration of pDQ191 into the $S$. venezuelae chromosome, plasmid excision, and retention of alternative alleles by homologous recombination.

Plating spores from these strains to give $100-150$ colonies per plate, and replica-plating to screen for antibiotic sensitivity and auxotrophy yielded about 120 $(10 \%)$ thiostrepton-sensitive (Thios) colonies, none of which required tryptophan for growth. 
Southern analysis of genomic DNA from seven of the Thio ${ }^{\mathrm{s}}$ strains digested with $\mathrm{MluI}$ and probed with pHJL400 showed no hybridization, as predicted if the plasmid had been excised by a double crossover. Probing the DNA with pDQ189 (carrying the $2.4 \mathrm{~kb}$ EcoRIHindIII S. venezuelae fragment from pDQ187 recloned in pHJL400) gave two hybridization patterns (Fig. 4a). In two of the seven strains (designated AP54), the size of the fragments $(16.5$ and $12 \mathrm{~kb})$ matched those given by the VS194 parent, and were thus consistent with an $M l u I$ site within the hybridizing region. The other five strains (AP55) showed only the single hybridizing fragment of approximately $28.5 \mathrm{~kb}$ predicted if the region lacked an internal MluI site. The results imply that the second crossover occurred at two alternative locations, one restoring the wild-type chromosomal sequence, and the other replacing it with the disrupted sequence (Fig. 4b).

In the nucleotide sequence of the pDQ187 insert, the restriction site for $M l u \mathrm{I}$ is at nt 1140-1145, near the middle of ORF2 (nt 251-2122), and in the domain encoding TrpE. Predictably, pDQ191, carrying the disrupted ORF2, failed to confer prototrophy when it was used to transform the E. coli trpE mutant JA200. However, $S$. venezuelae strain AP55, in which the disrupted ORF2 sequence had replaced the wild-type DNA, grew on minimal medium without a tryptophan supplement, implying endogenous synthesis. To confirm the hybridization evidence for mutation at the $M l u I$ site in pDQ191, the region was sequenced. This showed that ORF2 had been altered by the deletion of two bases (AA) at nt 1139-1140, shifting the reading frame to create a TGA stop codon at nt 1165-1167. The 304 aa polypeptide encoded by the mutated gene should constitute a severely truncated ASI; ASII should be absent. In an attempt to clone a second fragment of $S$. venezuelae DNA conferring anthranilic acid synthesis, a genomic library of S. venezuelae AP55 was prepared in pTZ18R and used to transform E. coli JA221 ( $\Delta$ trpE). Approximately 17000 transformants containing recombinant vector DNA were screened for growth on minimal medium, but no prototrophic colonies were obtained.

\section{DISCUSSION}

In encoding both ASI and ASII from domains in a single ORF the AS gene cloned from $S$. venezuelae ISP5230 (Paradkar et al., 1991a) resembles the $\operatorname{trp} E(G)$ gene used in tryptophan biosynthesis by R. meliloti (Bae et al., 1989) and Azospirillum brasilense (De Troch et al., 1997), and the $p h z B$ and $p h z E$ genes used in phenazine biosynthesis by $P$. aureofaciens and $P$. fluorescens, respectively (Pierson et al., 1995). In all of these genes, the N-terminal two-thirds of the encoded polypeptide is similar in sequence to the discrete ASI subunit proteins that exhibit aminase activity in enteric and other bacteria; the sequence of the C-terminal regions resembles the ASII subunit responsible for glutamine amidotransferase activity. However, the 624-637 aa products of the streptomycete and pseudomonad genes are smaller than the $\operatorname{TrpE}(\mathrm{G})$ polypeptides of $R$. meliloti and Azospirillum brasilense, which match the combined size (700-900 aa) of most pairs of discrete AS subunits. Sequence alignments indicate that size reduction in the $S$. venezuelae, $P$. aureofaciens and $P$. fluorescens enzymes has occurred in the distal portion of the ASI domain; the region between 150 and 400 aa from the $N$ termini closely matches the region $250-500$ aa from the $\mathrm{N}$ terminus of ASI in other organisms. Retention of Cterminal sequence would be consistent with the presumption from sequence conservation (Crawford, 1989) that this region is associated with important functional features in TrpE polypeptides.

The two-base deletion introduced by gene replacement into the ORF2 of S. venezuelae AP55 would be expected to change the translational reading frame 296 codons from the start site. Consequently, strain AP55 should lack both ASI and ASII activity. Because tryptophan is synthesized in $S$. venezuelae by the pathway common to most organisms (Paradkar et al., 1991a), the ability of AP55 to grow without a tryptophan supplement implies that it has an alternative means of synthesizing anthranilic acid. The evidence is supported by our inability to create auxotrophic mutants by integration within the gene of random, small fragments of ORF2 DNA cloned in pHJL400 (data not shown). The possible presence of a second enzyme with AS activity is raised by evidence obtained earlier (Francis et al., 1978) that partial purification of AS activity from $S$. venezuelae gave an enzyme with two discrete subunits different in size from the single bifunctional protein deduced from nucleotide sequence data in the present work. Although efforts to obtain a second gene by complementing $E$. coli JA221 $(\operatorname{trp} E)$ with cloned genomic DNA from the S. venezuelae AP55 were unsuccessful, this may well have been due to lack of expression in E. coli.

Southern hybridizations at relatively high stringency using as a probe the $2.4 \mathrm{~kb}$ BamHI-SacI S. venezuelae DNA fragment containing ORF1 and ORF2 detected only one hybridizing region in $S$. venezuelae genomic DNA (Paradkar et al., 1991a; see also Fig. 4a). Unique homologues were also present in other streptomycetes, though lower stringencies were sometimes needed (Paradkar et al., 1991a). At lower stringencies, additional hybridizing fragments might be detected in S. venezuelae; these could include related genes conferring AS activity, since genes propagated within an organism after duplication of a common ancestral form would be expected to undergo paralogous divergence (Crawford \& Milkman, 1991). $p$-Aminobenzoate synthase is related in structure and function to AS (Goncharoff \& Nichols, 1984), and could potentially substitute for this enzyme in streptomycetes. A potential candidate for residual AS activity would be the secondary metabolic pabAB gene identified in S. venezuelae (Aidoo et al., 1990; Brown et $a l ., 1996)$. Whether this gene can substitute for $\operatorname{trp} E(G)$ has not been tested. However, a cloned S. lividans DNA fragment complementing pab mutations in both $S$. lividans and E. coli (Arhin \& Vining, 1993) did not restore prototrophy in E. coli JA221 ( $\Delta t r p E)$ (data not included). The existence of more than one gene encoding AS activity in streptomycetes might explain why there 
are no previous reports of $\operatorname{trp} E$ or $\operatorname{trp} G$ mutants from these organisms.

Two genes for AS activity have been demonstrated in $P$. aeruginosa (Essar et al., 1990); one of the gene products functions in tryptophan biosynthesis and the other in production of the phenazine antibiotic pyocyanine. Under some conditions the functions are interchangeable, and either set of AS genes can complement trpE or $\operatorname{trp} G$ mutations in E. coli (Essar et al., 1990). Phenazines have been isolated from several actinomycetes (Gerber, 1984), but as yet $S$. venezuelae has not been reported to produce any secondary metabolites derived from anthranilic acid. The marked similarities between the AS from $S$. venezuelae and those reported from phenazineproducing pseudomonads point to a possible role in phenazine biosynthesis, and raise a question about the function of ORF2 in $S$. venezuelae. A persuasive argument in favour of a role in tryptophan biosynthesis is the presence immediately upstream of a small ORF with the characteristics of a $\operatorname{trpL}$ attenuator gene. Its predicted gene product is a polypeptide in the size range (14-19 amino acids) of trpL leader peptides from other bacteria (Bae et al., 1989). It resembles the $t r p L$ region associated with regulation of the trp operons in Brevibacterium lactofermentum and $R$. meliloti in containing three Trp codons in tandem; the leader peptides of enteric bacteria have two tandem Trp codons. Strong sequence similarity between the region predicted to generate the 3:4 stem structures in $S$. venezuelae, $R$. meliloti and $E$. coli suggests that the rho-independent transcriptional terminator known to form in the latter two bacteria probably forms also in S. venezuelae. The presence of a putative -10 hexamer upstream of the leader region, the absence of a recognizable -35 consensus sequence, and the existence nearby of a small direct repeat is consistent with a promoter containing auxiliary regulatory sequences.

An earlier suggestion (Paradkar et al., 1991b) that the concentration of tryptophan/tryptophanyl-tRNA in wild-type $S$. venezuelae mycelium is sufficient to cause feedback repression of AS synthesis was supported by the marked increase in AS activity that occurred when endogenous pool concentrations were lowered by introducing a $\operatorname{trp} C$ mutation. Supplementation of the mutant cultures with tryptophan provided further evidence of endproduct repression. However, the apparent ability of $S$. venezuelae to obtain anthranilic acid by more than one route raised a question about whether $\operatorname{trp} E(G)$ or the alternative process was the feedback target. This issue was addressed by introducing the ORF1 and ORF2 genes from $S$. venezuelae into $E$. coli trp mutants. As anticipated from earlier results (Paradkar et al., 1991b), E. coli JA200 ( $\triangle \operatorname{trpE})$ transformed to tryptophan independence by pDQ187 showed low AS activity, which did not change appreciably when cultures in minimal medium were supplemented with increasing concentrations of tryptophan. That the low AS activity was due to feedback from endogenous tryptophan was indicated by the response to tryptophan of E. coli W3110 trpCER transformed to prototrophy with pDQ187. Although the level of AS activity in transformants was low, and feedback repression saturated at a relatively low supplement concentration, the graded response to tryptophan suggested that the enzyme was involved in tryptophan biosynthesis. The low intensity of the effect might be attributed to imperfect regulation and/or weak expression of the ORF2 gene in the heterologous system.

Sensitivity to endproduct inhibition is reported to be a feature of AS involved in tryptophan biosynthesis (Zalkin, 1980; Ross \& Winkler, 1988), but not of the AS involved in biosynthesis of the secondary metabolite pyocyanine (Essar et al., 1990). Thus the concentrationdependent inhibition by tryptophan of AS activity in extracts from $S$. venezuelae VS153 implicates this activity in tryptophan biosynthesis. However, the response was weak: $44 \%$ inhibition with $2 \mathrm{mM}$ tryptophan compared with $75 \%$ inhibition of $R$. meliloti $\operatorname{TrpE}(\mathrm{G})$ obtained with only $5 \mu \mathrm{M}$ tryptophan by Bae $\&$ Crawford (1990). Moreover, the response in S. venezuelae cannot be unequivocally attributed to the ORF2 product because more than one AS activity may have been present in the cell extracts. The evidence currently available does not allow a firm decision on the physiological function of the AS gene cloned from S. venezuelae. Its association with systems for feedback regulation by tryptophan suggests that it is $\operatorname{trp} E(G)$, a key gene in the pathway for biosynthesis of this amino acid. On the other hand, the results from sequence alignments show a close evolutionary relationship with $p h z$ genes and implicate it in the production of a phenazine secondary metabolite.

\section{ACKNOWLEDGEMENTS}

We are grateful to Dr C. L. Hershberger, Eli Lilly Company, for providing pHJL400, and to Dr C. Yanofsky, Department of Biological Sciences, Stanford University, for the E. coli strains. The research was supported by the Natural Sciences and Engineering Research Council of Canada.

\section{REFERENCES}

Aidoo, D. A., Barrett, K. \& Vining, L. C. (1990). Plasmid transformation of Streptomyces venezuelae: modified procedures used to introduce the genes for $p$-aminobenzoate synthetase. $J$ Gen Microbiol 136, 657-662.

Altschul, S. F., Gish, W., Miller, W., Myers, E. W. \& Lipman, D. J. (1990). Basic local alignment search tool. J Mol Biol 215, 403-410.

Anzai, H., Kumada, Y., Hara, O., Murakami, T., Ito, R., Takano, S., Imai, S., Satoh, A. \& Nagaoka, K. (1988). Replacement of Streptomyces bygroscopicus genomic segments with in vitroaltered DNA sequences. J Antibiot 41, 226-233.

Arhin, F. F. \& Vining, L. C. (1993). Organization of the genes encoding $p$-aminobenzoic acid synthetase from Streptomyces lividans 1326. Gene 126, 129-133.

Bae, Y. M. \& Crawford, I. P. (1990). The Rhizobium meliloti $\operatorname{trp} E(G)$ gene is regulated by attenuation, and its product, anthranilate synthase, is regulated by feedback inhibition. J Bacteriol 172, 3318-3327.

Bae, Y. M., Holmgren, E. \& Crawford, I. P. (1989). Rhizobium meliloti anthranilate synthase: cloning, sequence and expression in Escherichia coli. J Bacteriol 171, 3471-3478. 
Brown, M. P., Aidoo, K. A. \& Vining, L. C. (1996). A role for $p a b A B$, a $p$-aminobenzoate synthase gene of Streptomyces venezuelae ISP5230, in chloramphenicol biosynthesis. Microbiology 142, 1345-1355.

Carter, P., Bedovelle, H. \& Winter, G. (1985). Improved oligonucleotide site-directed mutagenesis using M13 vectors. Nucleic Acids Res 13, 4431-4443.

Chater, K. F. \& Hopwood, D. A. (1989). Diversity of bacterial genetics. In Genetics of Bacterial Diversity, pp. 24-46. Edited by D. A. Hopwood \& K. F. Chater. New York: Academic Press.

Clarke, L. \& Carbon, J. (1976). A colony bank containing synthetic ColE1 hybrid plasmids representative of the entire $E$. coli genome. Cell 9, 91-99.

Crawford, I. P. (1989). Evolution of a biosynthetic pathway: the tryptophan paradigm. Annu Rev Microbiol 43, 567-600.

Crawford, I. P. \& Milkman, R. (1991). Orthologous and paralogous divergence, reticulate evolution and lateral gene transfer in bacterial trp genes. In Evolution at the Molecular Level, pp. 77-95. Edited by R. K. Selander, A. G. Clark \& T. S. Whittam. Sunderland, MA: Sinauer Associates.

De Troch, P., Dosselaere, F., Keijers, V., de Wilde, P. \& Vanderleyden, J. (1997). Isolation and characterization of the Azospirillum brasilense $\operatorname{trp} E(G)$ gene, encoding anthranilate synthase. Curr Microbiol 34, 27-32.

Denhardt, D. T. (1966). A membrane-filter technique for the detection of complementary DNA. Biochem Biophys Res Commun 23, 641-646.

Devereux, J., Haeberle, P. \& Smithies, O. (1984). A comprehensive set of sequence analysis programs for the VAX. Nucleic Acids Res 12, 387-395.

Doull, J., Ahmed, Z., Stuttard, C. \& Vining, L. C. (1985). Isolation and characterization of Streptomyces venezuelae mutants blocked in chloramphenicol biosynthesis. J Gen Microbiol 131, 97-104.

Doull, J. L., Vats, S., Chaliciopoulos, M., Stuttard, C., Wong, K. \& Vining, L. C. (1986). Conjugational fertility and location of chloramphenicol biosynthesis genes on the chromosomal linkage map of Streptomyces venezuelae. J Gen Microbiol 132, 13271338 .

Essar, D. W., Eberly, L., Hadero, A. \& Crawford, I. P. (1990). Identification and characterization of genes for a second anthranilate synthetase in Pseudomonas aeruginosa: interchangeability of the two anthranilate synthetases and evolutionary implications. J Bacteriol 172, 884-900.

Francis, M. M., Vining, L. C. \& Westlake, D. W. S. (1978). Characterization and regulation of anthranilate synthetase from a chloramphenicol-producing streptomycete. J Bacteriol 134, 1016.

Gerber, N. N. (1984). Microbial phenazines. In Handbook of Microbiology, 2nd edn, vol. V, Microbial Products, pp. 573-576. Edited by A. I. Laskin \& H. A. Lechevalier. Boca Raton, FL: CRC Press.

Goncharoff, P. \& Nichols, B. P. (1984). Nucleotide sequence of Escherichia coli pabB indicates a common evolutionary origin of $p$-aminobenzoate synthetase and anthranilate synthetase. J Bacteriol 159, 57-62.

Higgins, D. G. \& Sharp, P. M. (1989). Fast and sensitive multiple sequence alignment on a microcomputer. Comput Appl Biosci 5, 151-153.

Holmes, D. S. \& Quigley, M. (1981). A rapid boiling method for the preparation of bacterial plasmids. Anal Biochem 114, 193-200.

Hopwood, D. A., Bibb, M. J., Chater, K. F., Kieser, T., Bruton, C. J., Kieser, H. M., Lydiate, C. P., Smith, C. P., Ward, J. M. \&
Schrempf, H. (1985). Genetic Manipulation of Streptomyces: a Laboratory Manual. Norwich: John Innes Foundation.

Huang, L. H. \& Zalkin, H. (1971). Multiple forms of anthranilate synthase-anthranilate 5-phosphoribosyl pyrophosphate phosphoribosyl transferase from Salmonella typhimurium. J Biol Chem 246, 2338-2354.

Jones, A. \& Westlake, D. W. S. (1974). Regulation of chloramphenicol synthesis in Streptomyces sp. 3022a. Properties of arylamine synthetase, an enzyme involved in antibiotic synthesis. Can J Microbiol 20, 1599-1611.

Karger, B. D. \& Jessee, J. (1990). Preparation of single strand DNA from phagemids. Focus 12, 28-29.

Kieser, T. (1984). Factors affecting the isolation of cccDNA from Streptomyces lividans and Escherichia coli. Plasmid 12, 19-36.

Kushner, S. R. (1978). An improved method for transformation of Escherichia coli with ColE1-derived plasmids. In Genetic Engineering, pp. 17-23. Edited by $\mathrm{H}$. W. Boyer \& S. Nicosia. Amsterdam: Elsevier/North Holland Biomedical Press.

Landick, R., Turnbough, C. L., Jr \& Yanofsky, C. (1996). In Escherichia coli and Salmonella typhimurium: Cellular and Molecular Biology, 2nd edn, vol. I, pp. 1263-1286. Edited by F. C. Neidhardt and others. Washington, DC: American Society for Microbiology.

Larson, J. L. \& Hershberger, C. L. (1986). The minimal replicon of a streptomycete plasmid produces an ultrahigh level of plasmid DNA. Plasmid 15, 199-209.

Mavrodi, D. V., Ksenzenko, V. N., Boronin, A. M., Cook, J. R. \& Thomashow, L. S. (1995). Molecular characterization, nucleotide sequence and expression of phenazine biosynthesis genes in Pseudomonas fluorescens. GenBank accession no. L48616.

Paradkar, A. S., Stuttard, C. \& Vining, L. C. (1991a). Molecular cloning of the genes for anthranilate synthetase from Streptomyces venezuelae ISP5230. FEMS Microbiol Lett 78, 177-182.

Paradkar, A. S., Vining, L. C. \& Stuttard, C. (1991b). Characterization of tryptophan-requiring auxotrophs of Streptomyces venezuelae ISP5230. Can J Microbiol 37, 333-338.

Paradkar, A. S., Stuttard, C. \& Vining, L. C. (1993). Location of the genes for anthranilate synthase in Streptomyces venezuelae ISP5230: genetic mapping after integration of the cloned genes. J Gen Microbiol 139, 687-694.

Pierson, L. S., 3rd, Gaffney, T., Lam, S. \& Gong, F. (1995). Molecular analysis of genes encoding phenazine biosynthesis in the biological control bacterium Pseudomonas aureofaciens 30 84. FEMS Microbiol Lett 134, 299-307.

Potter, C. A. \& Baumberg, S. (1996). End-product control of enzymes of branched-chain amino acid biosynthesis in Streptomyces coelicolor. Microbiology 142, 1945-1952.

Ross, C. M. \& Winkler, M. E. (1988). Regulation of tryptophan biosynthesis in Caulobacter crescentus. J Bacteriol 170, 769-774.

Sambrook, J., Fritsch, E. F. \& Maniatis, T. (1989). Molecular Cloning: a Laboratory Manual. Cold Spring Harbor, NY: Cold Spring Harbor Laboratory.

Sanger, F., Nicklen, S. \& Coulson, A. R. (1977). DNA sequencing with chain-terminating inhibitors. Proc Natl Acad Sci USA 74, 5463-5467.

Smith, P. K. (1985). Measurement of protein using bicinchoninic acid. Anal Biochem 150, 6-85.

Smith, O. H. \& Yanofsky, C. (1963). Intermediates in the biosynthesis of tryptophan. Methods Enzymol 6, 590-597. 
Smithers, C. M. \& Engel, P. (1974). Gene-enzyme relationships of tryptophan mutants in Streptomyces coelicolor A3(2). Genetics 78, 799-808.

Southern, E. M. (1975). Detection of specific sequences among DNA fragments separated by gel electrophoresis. J Mol Biol 98, 503-517.

Strohl, W. R. (1992). Compilation and analysis of DNA sequences associated with apparent streptomycete promoters. Nucleic Acids Res 20, 961-974.

Stuttard, C. (1982). Temperate phages of Streptomyces venezuelae: lysogeny and host specificity shown by SV1 and SV2. J Gen Microbiol 128, 115-121.

Stuttard, C. (1983). Cotransduction of his and trp loci by phage SV1 in Streptomyces venezuelae. FEMS Microbiol Lett 20, 467-470.

Vieira, J. \& Messing, J. (1987). Production of single-stranded plasmid DNA. Methods Enzymol 153, 3-15.
Vining, L. C. \& Stuttard, C. (1994). Chloramphenicol. In Genetics and Biochemistry of Antibiotic Production, pp. 505-530. Edited by L. C. Vining \& C. Stuttard. Boston: Butterworth-Heinemann. Wright, F. \& Bibb, M. J. (1992). Codon usage in the G+C-rich Streptomyces genome. Gene 113, 55-65.

Yanofsky, C. (1981). Attenuation in the control of expression of bacterial operons. Nature 289, 751-758.

Yanofsky, C. (1984). Comparison of regulatory and structural regions of genes of tryptophan metabolism. Mol Biol Evol 1, 143-161.

Zalkin, H. (1980). Anthranilate synthase: relationships between bifunctional and monofunctional enzymes. In Multifunctional Proteins, pp. 123-149. Edited by H. Bisswanger \& E. SchminkeOtt. New York: Wiley.

Received 6 November 1997; revised 2 March 1998; accepted 13 March 1998. 